\title{
Editorial: Web-Based Learning: Innovations and Challenges
}

\author{
Mudasser F. Wyne* \\ Technology \&Health Sciences Center, School of Engineering and \\ Technology, National University, USA \\ E-mail: mwyne@nu.edu \\ *Corresponding author
}

\begin{abstract}
This special issue of the Knowledge Management \& E-Learning: an international journal(KM\&EL) aims to stimulate interest in the web based issues in both teaching and learning, expose natural collaboration among the authors and readers, inform the larger research community of the interest and importance of this area and create a forum for evaluating innovations and challenges. We intend to bring together researchers and practitioners interested in developing and enhancing web-based learning environment. The objectives for this attempt are to provide a forum for discussion of ideas and techniques developed and used in web based learning. In addition the issue can also be used for educators and developers to discuss requirements for web-based education. Both theoretical papers and papers reporting implementation models, technology used and practical results are included in the issue.
\end{abstract}

Keywords: Web-Based Learning, Innovations, Challenges.

Biographical notes: Mudasser F. Wyne Currently serving as a Professor of Computer Science at School of Engineering and Technology, National University, San Diego, USA. He is a co-lead faculty for BSc in Information Systems programs. Dr. Wyne has a Ph.D. in Computer Science, M.Sc. in Engineering and B.Sc., in Electrical Engineering. He has been in academics for $20+$ years and supervised over 50 graduate and undergraduate projects. Dr. Wyne is with the Accreditation Board of Engineering and Technology (ABET), USA for more than 8 years and is currently serving as commissioner for Computing Accreditation Commission. In addition, he is a guest editor for a journal, associate editor and serving on editorial boards for four international journals. He has also served as Chair and Co-Chair of numerous conferences, workshops, tracks and panels, in addition to serving on the program committee for around 50 international conferences. Dr. Wyne has given invited talks on numerous occasions and published number of articles in peer reviewed international journals and peer reviewed international conferences.

\section{Introduction}

This special issue of the Knowledge Management \& E-Learning: an international journal(KM\&EL) aims to stimulate interest in the web based issues in both teaching and learning, expose natural collaboration among the authors and readers, inform the larger research community of the interest and importance of this area and create a forum for evaluating innovations and challenges. We intend to bring together researchers and practitioners interested in developing and enhancing web-based learning environment. 
The objectives for this attempt are to provide a forum for discussion of ideas and techniques developed and used in web based learning. In addition the issue can also be used for educators and developers to discuss requirements for web-based education. Both theoretical papers and papers reporting implementation models, technology used and practical results are included in the issue.

The call for contributions resulted in a large number of submitted research papers on a variety of topics, including Information quality, role of administrators, chat discussions, learning style and navigation behavior and digital application of web engineering. Mona Alkhattabi et al (2010) in their paper on "Information quality framework for e-learning systems" talk about a new information quality framework that provides a comprehensive indication of the quality of information. The framework measure the quality based on information quality attributes grouped in intrinsic, contextual representation and accessibility dimensions. The paper submitted by Yang (2010) talks about the challenges and new roles played by the administrators in maintaining the quality of online education. Another paper is by Chima Adiele et al (2010). Their paper talks about advances in information and communication technologies and present an interactivity model to measure level of interactivity of students in a class. The paper by Stanley Loh et al (2010) presents a system that analyzes the themes discussed in a chat room and then recommends information sources according to the context of discussion. Theme of discussion is identified by using text mining and recommendations are based on user profile. Nabila Bousbia et al (2010) in their paper present their research on establishing a relationship between the learner's navigation behavior and their learning style from the analysis of browsing behavior. In the next paper Ezendu Ariwa and Morris Michael (2010) discuss a challenge faced by the business community to promote and establish their business. Xun Ge et al (2010) in their paper present a qualitative study of the experiences of faculty members in transitioning from one learning management system to another system. In the last paper, Olaniran et al (2010) examine cross cultural challenges in implementing Web-based instruction, through a discussion of cultural dimensions, cultural technology perceptions, language barriers, and user needs.

\section{Acknowledgements}

The call for paper for this issue generated lot of interest in the research community so the guest editor wish to express his gratitude to all authors who submitted their papers for their effort and support for this special issue. I would also like to thank the reviewers, for their time and support, who submitted reviews and suggestions to authors for improving the quality of the papers, especially those accepted for this issue. I am also indebted to Editors-in-Chief Dr. Maggie M. Wang and Dr. Stephen J.H. Yang for the opportunity to finally make this special issue a reality, it would have not been possible without their help and support.

\section{References}

1 Adiele, C., \& Nwanze, E. D. (2010). The Dynamics of Interactivity Modeling for eLearning. Knowledge Management \& E-Learning: An International Journal, 2(4), 370-384. 
2 Alkhattabi, M., Neagu, D., \& Cullen, A. (2010). Information Quality Framework for e-Learning Systems. Knowledge Management \& E-Learning: An International Journal, 2(4), 340-362.

3 Anonymous (2009). What is e-learning. Retrieved November 30, 2009, from http://www.tech-faq.com/E-learning.shtml.

4 Ariwa, E., \& Michael, M. (2010). Facilities Management and Digital Application of Web Engineering: Implications for Business Informatics Systems. Knowledge Management \& E-Learning: An International Journal, 2(4), 422-432.

5 Bousbia, N., Rebai, I., Labat, J. M., \& Balla, A. (2010). Analysing the Relationship between Learning Styles and Navigation Behaviour in Web-Based Educational System. Knowledge Management \& E-Learning: An International Journal, 2(4), 400-421.

6 Downes, S. (2005, October 17). E-learning 2.0. National Research Council of Canada. Retrieved November 30, 2009, from http://www.elearnmag.org/subpage.cfm?article=29-1\&section=articles.

7 Ge, X., Lubin, I., \& Ke Zhang, K. (2010). An Investigation of Faculty's Perceptions and Experiences when Transitioning to a New Learning Management System. Knowledge Management \& E-Learning: An International Journal, 2(4), 433-447.

8 Ivanescu, A., Barda, I, \& Vladicescu, F. P. (2008). Distance learning answering students' needs: The example of the interactive e-learning environment (IELE). The Proceedings of the Fourth International Scientific Conference on E-learning and Software for Education, Bucharest.

9 Kilgore, D.W. (2001). Critical and postmodern perspectives on adult learning. New Directions for Adult and Continuing Education, 2001(89), 53-62.

10 Logan, R.K. (2000). The sixth language: Learning a living in the Internet age. Physics.utoronto.ca. Retrieved November 30, 2009, from http://physics.utoronto.ca.

11 Logan, R.K. (1997). The fifth language: Learning and living in the computer age. Toronto: Stoddard Pub.

12 Loh, S., Lichtnow, D., Kampff, A. J. C., \& de Oliveira, J. P. M. (2010). Recommendation of Complementary Material during Chat Discussions. Knowledge Management \& E-Learning: An International Journal, 2(4), 385-399.

13 Mushtaha, A., \&, Troyer, O. D. (2007). Cross-cultural understanding of content and interface in the context of e-learning systems. Lecture Notes in Computer Science (Volume 4559), 164-173. Springer Berlin / Heidelberg.

14 Olaniran, B. A., Williams, I. M. , \& Rodriguez, N. (2010). Cross-Cultural Challenges in Web-Based Instruction. Knowledge Management \& E-Learning: An International Journal, 2(4), 448-465.

15 Srimathi, H., \& Srivatsa, S. K. (2008). Knowledge representation in personalized elearning. Academic Open Internet Journal, 23. Retrieved November 30, 2009, from http://www.acadjournal.com/2008/v23/part6/p4/

16 Yang, Y. (2010). Roles of Administrators in Ensuring the Quality of Online Programs. Knowledge Management \& E-Learning: An International Journal, 2(4), 363-369. 